\title{
DECISION SUPPORT SYSTEM SELECTION OF THE BEST CITILINK AGENT CALL CENTER USING THE FUZZY AHP METHOD (Analytical Hierarchy Process)
}

\section{(Case Study: PT. Infomedia Surabaya Call Center Citilink)}

\author{
${ }^{1}$ M. MAHAPUTRA HIDAYAT, ${ }^{2}$ SYARIFUL ALIM, ${ }^{3}$ DHANU BUDI PANGESTU \\ Department of Informatics Engineering, Bhayangkara University of Surabaya \\ Ahmad Yani Street 114 Surabaya, Post Code 60231 \\ e-mail:1'mahaputra@ubhara.ac.id, ${ }^{2}$ alim@ubhara.ac.id, ${ }^{3}$ dhanubudipangestu@gmail.com
}

\begin{abstract}
For the selection of employees, there are usually many factors in fulfilling the assessment in order to get a maximum target. Especially in the field of call centers, it is required to have qualified skills which can solve problems complained of by customers. So that as a call center who receives incoming calls or can be called inbound calls, it must be the key to solving problems and be able to convey good suggestions. However, to get the value of the agent so that its performance is good, there are parameters that must be achieved, namely acd call, acd time, aux time, available time, staffed time and agent skill. best. By doing this, the monitoring system is very easy and more efficient to find out which agents are underperforming or agents who have reached the performance target. For this reason, an application with a case study was created in order to achieve the maximum target. This application will greatly help the team, namely Teamleader, Taber, Spv, Manager as they play an important role in evaluating agents in their performance.
\end{abstract}

Keywords: Monitoring system, Fuzzy Ahp, Call Center, Best Employees

\section{INTRODUCTION}

Basically every company that is founded has the hope that in the future it will experience rapid development in the scope of business and want the creation of high productivity in the field of work. The labor or human factor is important, because humans are the users and movers and determiners of all activities in the company. The existence of quality human beings will greatly determine the success of the company in achieving its goals.

PT. Infomedia Nusantara is a subsidiary of the Telkom Group that provides Contact Center services through Call Center services. It is an organization formed to serve customers by telephone for 24 hours in order to provide convenience and comfort, in obtaining information anytime, anywhere. To maintain a good image, employees must have a stable performance and in accordance with the rules of the company. Given the important role of the Call Center PT. Infomedia Nusantara, especially the Citilink Surabaya call center service division, always strives to maintain the quality of Call Center services so that customers always get the right, accurate, easy information and a satisfactory service attitude. To achieve these efforts, Call Center employees, especially the Citilink Surabaya division, have been provided with clear performance standards and periodic performance assessments are carried out by the Team Leader and Quality Control with the aim that the quality or performance of Citilink Call Center employees is in accordance with the company's parameters to achieve Service level $100 \%$.

The number of service fields engaged in call centers encourages companies to be able to increase employee productivity.The rapid development of technology certainly requires PT. Infomedia, especially the Citilink Surabaya Call Center division, is able to face the existing challenges. Experienced management and infrastructure supported by high technology are one of the advantages of the company to be able to compete with other contact center service 
companies. To achieve these efforts, a method is needed to solve problems or evaluate employee performance to make it even better with the assessment achieved, to solve problems in the assessment target, the method used is the Fuzzy Ahp Method and for Fuzzy AHP is an analytical method developed from traditional AHP. . Although AHP is commonly used in dealing with qualitative and quantitative criteria in MCDM, fuzzy AHP is considered better in describing vague employee performance values than traditional AHP. the factors of logic, intuition, experience, knowledge, emotions, and feelings are tried to be optimized in a systematic process. In addition, to determine the choice of the level of importance between criteria by using an assessment in intervals compared to an assessment with exact numbers. To overcome these problems, a modified technique and a fuzzy set technique in AHP called Fuzzy AHP have been developed. So with the development of this system there will be conditions that are expected, namely monitoring call center performance faster and taking call center performance values at Citilink inbound agents more easy, consistent, objective and centralized.

The application of maximum targets in serving customers during shift work certainly requires agents to be able to work harder so that they do not have free time other than rest time which must be utilized in such a way as to eliminate boredom all day working. The application of performance like this, of course, has an influence on the work productivity of PT.Infomedia employees, especially the Citilink Surabaya Call Center division.

For this reason, the company has values and targets for the quality of employees so as not to weaken the quality of service for customers, because this will be very important determine value for employees as well as for the company. If this matter gets more attention from the company, the profits obtained are certainly very large and useful for the present and the future. Companies can get benefits in the form of achieving goals and high productivity and for employees will get high performance. Based on the description above, in this study the author takes the title: "decision support system Selection of the best Citilink Call center agent with the FAHP method at PT. Infomedia Surabaya".

\subsection{Problem Limitation}

1. Each contact center agent is assumed to have the same customer handling capabilities.

2. Calculation of call volume only on incoming calls (inbound calls).

3. The talk time data uses the data in the recap that has been made

4. Assume that all calls that enter the system only go to the services provided by the contact center agent

5. The data used for research is in the period 2019-2020

6. Agent data taken in the inbound division of 20 people.

7. The achievement of the number of service level income scores is more than the maximum performance.

8. Using criteria 5 ( five), namely are ACD call, ACD time, AUX time, AVAIL time, STAFFED time,

9. Fuzzy agent skills are used to determine the achievement value.

\subsection{Problem Formulation}

1. What parameters affect the achievement of service level .

2. How is the influence of the parameters contained in the service level, on the achievement of the service level .

\subsection{Research Objectives}

In the research that will be carried out, the purpose of this research is to are:

1. Knowing what parameters affect the achievement of service level .

2. Knowing the extent to which the parameters in the service level affect the achievement of the service level.

3. Knowing the achievement of the performance of the agents to get the target value achieved . 


\section{BASIC FOR THEORY}

\subsection{Triangular Fuzzy Number (TFN)}

The set theory that helps in measuring the concept of inguity related to human subjective judgments uses the linguistic variable of the Triangular Fuzzy Number (TFN) number. This TFN was developed to describe linguistic variables with certainty. TFN is also useful for describing and processing information in a fuzzy scope . The essence of the fuzzy AHP method lies in pairwise comparisons that explain the relative changes between pairs of decision attributes in the same hierarchy, then the comparison is described by a ratio scale that corresponds to the value of the fuzzy scale. Number triangular fuzzy is symbolized by $\mathrm{M}$ and the terms of membership function 5 (five) scale linguistic variables can be seen in table 1 .

Table 1.1

\begin{tabular}{|c|l|c|c|}
\hline \multicolumn{5}{|c|}{ Tringular Number Chang Fuzzy Scale Table } \\
\hline $\begin{array}{c}\text { AHP's interest } \\
\text { intensity is } \\
\text { important }\end{array}$ & \multicolumn{1}{|c|}{ Linguistics Association } & $\begin{array}{c}\text { Triangle } \\
\text { Fuzzy Number } \\
(\text { TFN) }\end{array}$ & $\begin{array}{c}\text { Reciprocal } \\
\text { (opposite) }\end{array}$ \\
\hline 1 & Ratio of the same n elements (Just Equal) & $(1,1,1)$ & $(1,1,1)$ \\
\hline 2 & Intermediate (Intermediate) & $(1 / 2,1,3 / 2)$ & $(2 / 3,1,2)$ \\
\hline 3 & $\begin{array}{l}\text { One element is quite important from } \\
\text { the other (Moderately Important) }\end{array}$ & $(1,3 / 2,2)$ & $(1 / 2,2 / 3,1)$ \\
\hline 4 & $\begin{array}{l}\text { Intermediate, one element is } \\
\text { more important than the other }\end{array}$ & $(3 / 2,2,5 / 2)$ & $(2 / 5,1 / 2,2 / 3)$ \\
\hline 5 & $\begin{array}{l}\text { One element is more important than the } \\
\text { other (Strongly Important) }\end{array}$ & $(2,5 / 2,3)$ & $(1 / 3,2 / 5,1 / 2)$ \\
\hline 6 & Intermediate (Intermediate) & $(5 / 2,3,7 / 2)$ & $(2 / 7,1 / 3,2 / 5)$ \\
\hline 7 & $\begin{array}{l}\text { One element is more important than the } \\
\text { other (Very Strong) }\end{array}$ & $(3,7 / 2,4)$ & $(1 / 4,2 / 7,1 / 3)$ \\
\hline 8 & Intermediate (Intermediate) & $(7 / 2,4,9 / 2)$ & $(2 / 9,1 / 4,2 / 7)$ \\
\hline 9 & $\begin{array}{l}\text { One element is absolutely more } \\
\text { important than the other (Extremely } \\
\text { Strong) }\end{array}$ & $(4,9 / 2,9 / 2)$ & $(2 / 9,2 / 9,1 / 4)$ \\
\hline
\end{tabular}

\subsection{Fuzzy linear curve up}

Linear ascending, namely the set starting from the domain that has a membership value of 0 to the domain that has a membership value of 1 or starting from the bottom left side to the top right. Examples of calculations as follows:

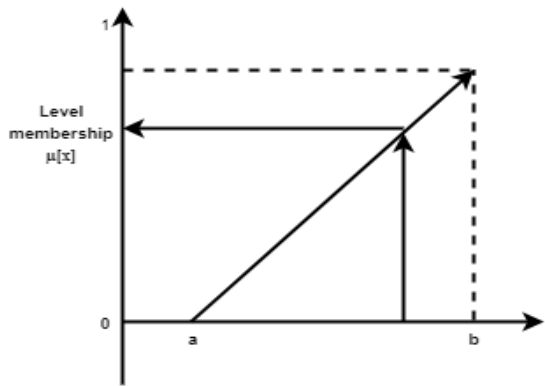

Figure 2.2 Graph of an Upward Linear Curve 


$$
\mu[x]= \begin{cases}0 ; & \mathrm{X} \leq \mathrm{a} \\ \frac{x-a}{b-a} & 2 \mathrm{a} \leq \mathrm{x} \leq \mathrm{b} \\ 1 ; & \mathrm{X} \geq \mathrm{b}\end{cases}
$$

\section{Analytical Hierarchy Process (AHP)}
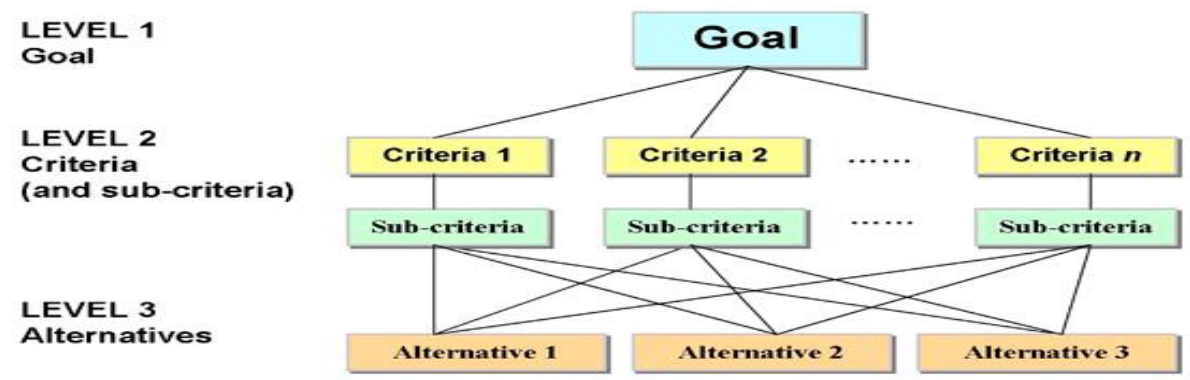

Figure 2.3 Analytical Hierarchy Process (AHP)

AHP is a decision support model developed by Thomas L. Saaty. This decision support model will describe a complex multi-factor or multi-criteria problem into a hierarchy. According to Saaty (1993), hierarchy is defined as a representation of a complex problem in a multi-level structure where the first level is the goal, followed by the level of factors, criteria, sub-criteria, and so on down to the last level of alternatives. With a hierarchy, a complex problem can be broken down into groups which are then arranged into a hierarchical form so that the problem will appear more structured and systematic. always greater than or equal to $\mathrm{n}$ that is $\lambda$ mak. $\geq \mathrm{n}$. The difference between $\lambda$ mak. to $\mathrm{n}$ can be used to examine how much inconsistency exists in A, where the average is stated as follows (saaty, 2002) :

$$
C I=\frac{\lambda \text { maks }-\mathrm{n}}{\mathrm{n}-1}
$$

Where :

$\mathrm{CI}=$ Consistency Index

$\lambda$ maximum $=$ The largest eigenvalue of a matrix of order $n$

A pairwise comparison matrix is declared consistent if the consistency ratio ( CR ) $\leq 10 \%$. CR can be calculated using the following formula:

$$
C R=\frac{C I}{R I}
$$

Where :

$\mathrm{CR}=$ Consistency Ratio

$\mathrm{RI}=$ Random generator value

The following table Random Index ( RI ) for matrices size 1 to 15:

Tabel 2.1 Tabel Random Index (RI)

\begin{tabular}{|c|c|c|c|c|c|c|c|c|c|c|c|c|c|c|}
\hline $\mathbf{n}$ & 1.2 & 3 & 4 & 5 & 6 & 7 & 8 & 9 & 10 & 11 & 12 & 13 & 14 & 15 \\
\hline $\mathbf{R i}$ & 0.00 & 0.58 & 0,90 & 1.12 & 1.24 & 1.32 & 1.41 & 1.45 & 1.49 & 1.51 & 1.48 & 1.56 & 1.57 & 1.59 \\
\hline
\end{tabular}

Source:-Saaty(1994) 
The steps in calculating the AHP method are as follows :

1. Comparison of criteria $(\mathrm{C})$ in pairs using the Saaty value scale in accordance with predetermined criteria, namely ACD Call (C1), ACD Time (C2), AUX Time (C3), Avail Time (C4), Staffed Time (C5), and Achievements (C6).

Table 2.2 Comparison of Paired Criteria

\begin{tabular}{|c|c|c|c|c|c|c|}
\hline $\mathrm{C}$ & $\mathrm{C} 1$ & $\mathrm{C} 2$ & $\mathrm{C} 3$ & $\mathrm{C} 4$ & $\mathrm{C} 5$ & $\mathrm{C} 6$ \\
\hline $\mathrm{C} 1$ & 1 & 5 & 5 & 5 & 5 & 5 \\
\hline $\mathrm{C} 2$ & $1 / 5$ & 1 & 3 & 3 & 3 & 3 \\
\hline $\mathrm{C} 3$ & $1 / 5$ & $1 / 3$ & 1 & 1 & 1 & 1 \\
\hline $\mathrm{C} 4$ & $1 / 5$ & $1 / 3$ & $1 / 1$ & 1 & 1 & 1 \\
\hline $\mathrm{C} 5$ & $1 / 5$ & $1 / 3$ & $1 / 1$ & $1 / 1$ & 1 & 1 \\
\hline $\mathrm{C} 6$ & $1 / 5$ & $1 / 3$ & $1 / 1$ & $1 / 1$ & $1 / 1$ & 1 \\
\hline
\end{tabular}

2. Divide each column value of the paired criteria comparison results by the value of the addition.

Table 2.3 Column Division of Pairwise Comparison Results

\begin{tabular}{|c|c|c|c|c|c|c|}
\hline C & C1 & C2 & C3 & C4 & C5 & C6 \\
\hline C1 & $1 / 2,00$ & $5 / 7,33$ & $5 / 12,00$ & $5 / 12,00$ & $5 / 12,00$ & $5 / 12,00$ \\
\hline C2 & $0,20 / 2,00$ & $1 / 7,33$ & $3 / 12,00$ & $3 / 12,00$ & $3 / 12,00$ & $3 / 12,00$ \\
\hline C3 & $0,20 / 2,00$ & $0,33 / 7,33$ & $1 / 12,00$ & $1 / 12,00$ & $1 / 12,00$ & $1 / 12,00$ \\
\hline C4 & $0,20 / 2,00$ & $0,33 / 7,33$ & $1 / 12,00$ & $1 / 12,00$ & $1 / 12,00$ & $1 / 12,00$ \\
\hline C5 & $0,20 / 2,00$ & $0,33 / 7,33$ & $1 / 12,00$ & $1 / 12,00$ & $1 / 12,00$ & $1 / 12,00$ \\
\hline C6 & $0,20 / 2,00$ & $0,33 / 7,33$ & $1 / 12,00$ & $1 / 12,00$ & $1 / 12,00$ & $1 / 12,00$ \\
\hline
\end{tabular}

3. Adding up each row of criteria for calculating the value of the consistency matrix (CM) then dividing the results of the weighted criteria.

Table 2.4 Sum of the Results of Calculation of the Consistency of the Matrix

\begin{tabular}{|c|c|c|}
\hline C & $\Sigma \mathrm{CM}$ & $\Sigma$ \\
\hline $\mathrm{C} 1$ & $3,10 / 0,47$ & 6,53 \\
\hline $\mathrm{C} 2$ & $1,26 / 0,21$ & 6,11 \\
\hline $\mathrm{C} 3$ & $0,48 / 0,08$ & 6,05 \\
\hline $\mathrm{C} 4$ & $0,48 / 0,08$ & 6,05 \\
\hline C5 & $0,48 / 0,08$ & 6,05 \\
\hline C6 & $0,48 / 0,08$ & 6,05 \\
\hline
\end{tabular}

4. Calculating the value of Lamda Max ( $\square \max$ ) by sharing the value of the sum of consistency matrix calculation is divided on many criteria on which the criterion $(\mathrm{C})=6$

$$
\begin{gathered}
\lambda \max =(6.53+6.11+6.05+6.05+6.05+6.05) / 6 \\
=6.14 \\
C R=\frac{0,03}{1,24}=0,02
\end{gathered}
$$

a. Doing Fuzzification for Achievement Criteria

In this process, that is to perform fuzzification calculations for the value of the achievement criteria by using an ascending linear membership degree. To make a graph of an ascending linear curve, for calculations as an example of taking a membership degree sample for an agent representative, it can be taken with the agent name Eka Bayu for more details as follows. 


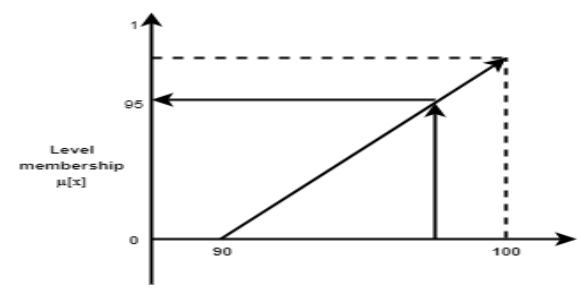

Figure 2.4 fuzzy graph of an ascending linear curve

$$
\begin{aligned}
& \mathrm{X} \leq \mathrm{a} \quad \text { for the formulation process in an ascending linear curve so } \\
& \mathrm{a} \leq \mathrm{x} \leq \mathrm{b} \text { the way to calculate it is as follows: } \\
& \mathrm{X} \geq \mathrm{b} \\
& \mu[x]=\left\{\begin{array}{c}
0 \\
x-a \\
b-a \\
1 ;
\end{array}\right. \\
& \mu \text { great }[29]=\frac{99,50-90}{100-90} \\
& =\frac{9,5}{10} \\
& =25 \text { Result }
\end{aligned}
$$

Table 2.5 Results of Calculation of Fuzzification of Achievement Criteria.

\begin{tabular}{|c|c|c|c|c|c|}
\hline Alternative & Score & Max & Min & $\begin{array}{c}\text { Level } \\
\text { Membership }\end{array}$ & $\%$ \\
\hline Eka Bayu S (A1) & 99.50 & 100 & 90 & $(99.50-90) /(100-90)$ & 95 \\
\hline Yuxun Ernawati (A2) & 99.80 & 100 & 90 & $(99.80-90) /(100-90)$ & 98 \\
\hline Ning Agus L (A3) & 98.00 & 100 & 90 & $(98.00-90) /(100-90)$ & 80 \\
\hline Mey Dxxiana (A4) & 98.00 & 100 & 90 & $(98.00-90) /(100-90)$ & 80 \\
\hline Erna Diah L (A5) & 95.30 & 100 & 90 & $(95,30-90) /(100-90)$ & 53 \\
\hline
\end{tabular}

because in alternative selection agent call center only choose one alternative, the system displays the results. Table 2.6 the ranking a Alternative.

\begin{tabular}{|c|c|c|}
\hline Alternative & $\Sigma$ & $\%$ \\
\hline Eka Bayu S & 3.03 & 43.28 \\
\hline
\end{tabular}

So that of the results of these decisions are Eka Bayu S which can be recommended.

\section{ANALYSIS AND DESIGN SYSTEM}

\subsection{System Flowchart}

Flowchart can be defined briefly that serves to graphically depict the steps and sequences of procedures of a program. Monologic flowchart of analysts and programmers to break down problems into smaller segments and help in analyzing other alternatives in the operation of each function. Flowcharts are usually to make it easier if there is a problem, especially a problem that can be studied and can be evaluated further, so the role in making the system is really needed for the flowchart so that you know the problems that can be solved properly and accurately. 


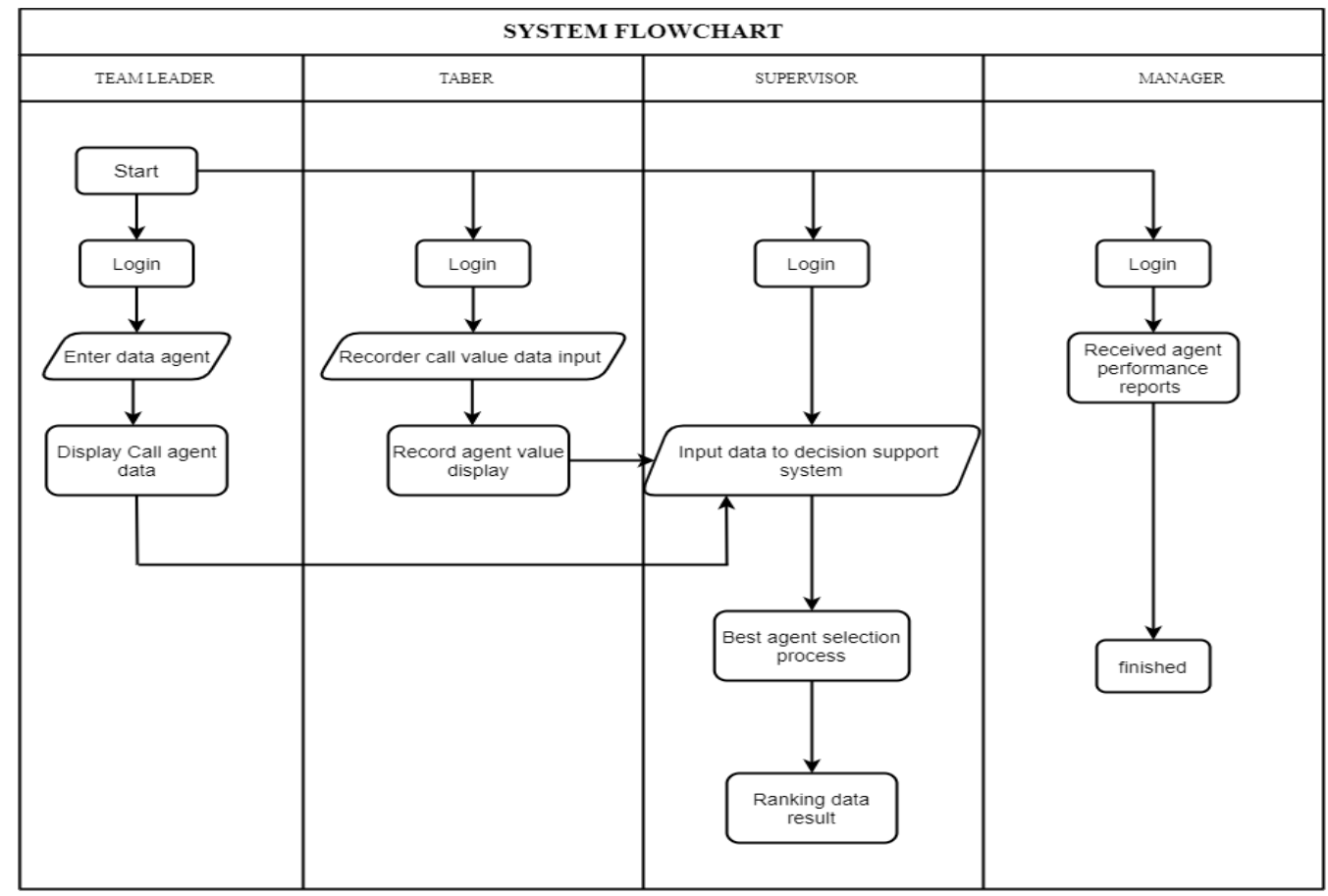

Figure 2.7 flowchart System

\section{RESULTS AND DISCUSSION}

\subsection{Test Results}

The following are the results where testing occurs when testing the path or flow of the application of the best agent selection decision support system using the Fuzzy Ahp method in the case study of PT. infomedia Nusantara Surabaya will be explained in detail for the functions that happen.

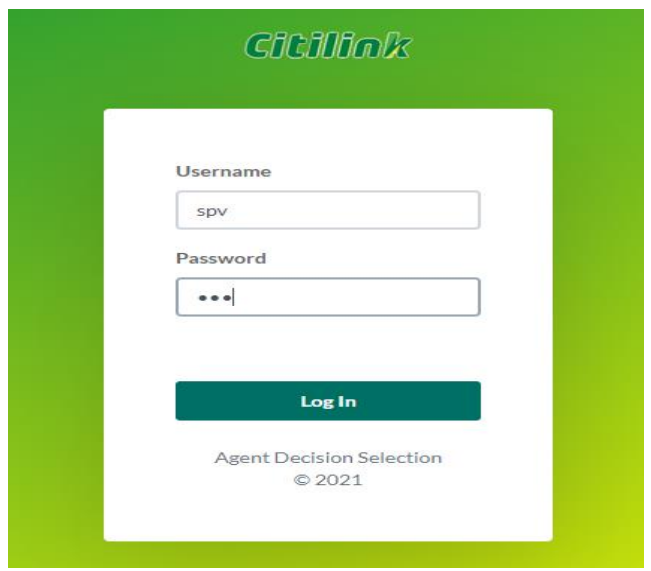

Figure 4.1 Login 


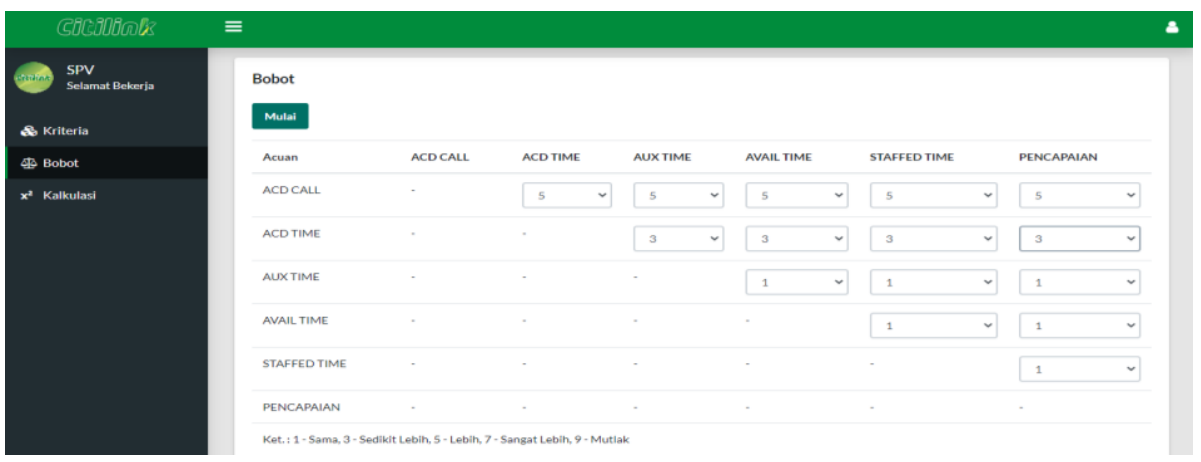

Picture 4.2 The calculation process method

\begin{tabular}{|c|c|c|c|c|c|c|c|c|c|}
\hline cateationls & & & & & & & & & \\
\hline \multirow[t]{2}{*}{ SPreting SPV } & \multicolumn{9}{|l|}{ Bobot } \\
\hline & \multicolumn{9}{|l|}{ Selesai } \\
\hline Bobot & Acuan & ACDCALL & ACD TIME & AUX TIME & AVAll TIME & STAFFED TIME & PENCAPAIAN & $\Sigma$ & w \\
\hline \multirow[t]{6}{*}{$x^{2}$ Kalkulasi } & ACDCALL & 0.5000 & 0.6818 & 0.4167 & 0.4167 & 0.4167 & 0.4167 & 2.8485 & 0.4747 \\
\hline & ACD TIME & 0.1000 & 0.1364 & 0.2500 & 0.2500 & 0.2500 & 0.2500 & 1.2364 & 0.2061 \\
\hline & AUXTIME & 0.1000 & 0.0455 & 0.0833 & 0.0833 & 0.0833 & 0.0833 & 0.4788 & $0.079 \mathrm{~s}$ \\
\hline & AVALLTIME & 0.1000 & 0.0455 & 0.0833 & 0.0833 & 0.0833 & 0.0833 & 0.4788 & 0.0798 \\
\hline & STAFFED TIME & 0.1000 & 0.0455 & 0.0833 & 0.0833 & 0.0833 & 0.0833 & 0.4788 & 0.0798 \\
\hline & PENCAPAIAN & 0.1000 & 0.0455 & 0.0833 & 0.0833 & 0.0833 & 0.0833 & 0.4788 & 0.0798 \\
\hline \multirow[t]{2}{*}{$\begin{array}{l}\text { SPV } \\
\text { Selamat Bekeria }\end{array}$} & Acuan & ACDCALL & ACD TIME & AUX TIME & AVALLTIME & STAFFED TIME & \multicolumn{2}{|c|}{ PENCAPAIAN } & t \\
\hline & ACDCALL & 0.4747 & 1.0303 & 0.3990 & 0.3990 & 0.3990 & \multicolumn{2}{|l|}{0.3990} & .5319 \\
\hline \multirow{2}{*}{$\begin{array}{l}28 \text { Kriteria } \\
40 \text { Bobot }\end{array}$} & ACD TIME & 0.0949 & 0.2061 & 0.2394 & 0.2394 & 0.2384 & \multicolumn{2}{|l|}{0.2394} & S,1078 \\
\hline & AUXTIME & 0.0949 & 0.0687 & 0.0799 & 0.0798 & 0.0798 & \multicolumn{2}{|l|}{0.0798} & 5.0506 \\
\hline \multirow{7}{*}{$x^{2}$ Kalkulasi } & AVAll time & 0.0949 & 0.0887 & 0.0798 & 0.0798 & 0.0798 & \multicolumn{2}{|l|}{0.0798} & .0506 \\
\hline & STAFFED TIME & 0.0949 & 0.0687 & 0.0798 & 0.0798 & 0.0798 & \multicolumn{2}{|l|}{0.0798} & .0506 \\
\hline & PENEAPAIAN & 0.0949 & 0.0687 & 0.0798 & 0.0798 & 0.0798 & \multicolumn{2}{|l|}{0.0798} & .0506 \\
\hline & & & & & & & & $\lambda_{\max }$ & .1.1404 \\
\hline & & & & & & & & c1 & .0281 \\
\hline & & & & & & & & $C R$ & 0.0226 \\
\hline & & & & & & & & $(0-0.1)$ & conalisten \\
\hline
\end{tabular}

Picture 4.3 result of calculation method

\section{CLOSING}

\subsection{Conclusion}

Based on the results of research and discussion that has been done in the previous. Therefore, a conclusion is drawn which states that:

a. The decision support system for selecting the best Citilink agent using the Fuzzy Ahp method, case study of PT. Infomedia Nusantara Surabaya, is running well. Where the results of the function test run well.

b. With this application, it can be used to monitor the performance of agents/employees without having to use Microsoft office as an intermediary

\subsection{Suggestions}

In the results of the research that has been carried out, drawing conclusions from the conclusions, suggestions are needed because maybe this can be useful for PT. Infomedia, especially the Citilink Surabaya Call center division, as follows:

a. The user must take advantage of the application that has been made to serve as a medium to find a report card for the agent's performance data. 
b. The implementation of the system will run well and smoothly if all related parties support the issuance of an employee performance decision support system application for monitoring data.

c. The process of making an application, no matter how good it is, has an expiration date or a period where it must be necessary or follow up analysis and auditing is useful to improve whether or not the development process is feasible or not to meet the needs in the Citilink call center

\section{REFERENCES}

[1]. Arisandi, Diki. 2020. "Lecturer Performance Monitoring System at Private Higher Education Institutions (Case Study: Abdurrab University).” 11(x): 196-205.

[2]. Fajri, Muhammad et al. 2018. "Implementation of the Fuzzy Analytic Hierarchy Process (F-AHP) Method in Determining Specialization in MAN 2 Serang City." 2(5): 2109-17.

[3]. Scientific, Journal, Computational Informatics, Jl Dipati, and Ukur No. 2013. "ASSET AND INVENTORY DATA MONITORING SYSTEM, University Computer Indonesia, Scientific Journal of Computers and Informatics (KOMPUTA)." 2(1): 1-6.

[4]. Kustian, Nunu, Aan Risdiana, Dudi Parulian, and Customer Service. 2019. "Development of a Database System in Making Call Center Monitoring Applications." 4(2502).

[5]. Lahallo, Jim, and Mega Fitriana. 2018. "Designing a Monitoring System for the Implementation of the STIMIK Student Work Practice on November 10, Jayapura." : 519-23.

[6]. Methods, Fuzzy-ahp As, Site Selection, and Billboards. 1990. "1 , 2 , 2 1.” : 2-5.

[7]. rincy, S. 2016. "Comparison of Triangular and Trapezoidal Fuzzy Membership Function.” (8): 46-51.

[8]. Prioritize, Define, Subscribers Visit, and GO to the Gallery. 2016. "FUZZY ANALYTICAL HIERARCHY PROCESS APPLICATION TO DETERMINE CUSTOMER PRIORITIES VISITING THE GALLERY (Case Study In Secondhand Semarang).” 5:239-48.

[9]. Purwokoaji, Deddy Kusbianto, Meyti Eka Apriani, and Rizky Purnamasari. 2002. "DESCRIPTION SYSTEM OF RASKIN RECIPIENT USING." : 41-46.

[10]. Son, Magala. "Sales Partner Monitoring Application at PT. Coca Cola Amatil Indonesia Banjarbaru." : 1495-1504.

[11]. Riyanto, Nikko Putra, and Tarimantan Sanberto Saragih. 2019. "Reminder System And Project Monitoring For Web-Based Employee Performance Assessment.” 08(September): 172-83.

[12]. Sains, Jurnal, Herfia Rhomadhona, and Tri Murti Ningsih. 2018. "Web-Based Meter Reading Complaint Monitoring Information System at PT. PLN (Persero) Banjarmasin Area.” 4.

[13]. Saputra, Aditya, Imam Fahrur Rozi, and Ely Setyo Astuti. 2002. "ABDULRACHMAN SALEH USING FAHP METHOD (FUZZY ANALYTICAL HIERARCHY PROCESS)."

[14]. Yunus, Amak, and Eko Prasetyo. 2018. "APPLICATION OF FUZZY AHP FOR IMPROVEMENT OF PRECISION AND Abstraction of Introduction to Literature Review.” I(1): 21-33. 
